\title{
Emergent curriculum in basic education for the new normality in Peru: orientations proposed from mathematics education
}

\author{
Luis Miguel Maraví Zavaleta ${ }^{1}$ (D)
}

Accepted: 4 August 2021 / Published online: 27 August 2021

(c) The Author(s), under exclusive licence to Springer Nature B.V. 2021

\begin{abstract}
The Peruvian basic education and its curriculum have been impacted by the COVID-19 pandemic. As a result, certain trends and phenomena have emerged, which shape the new normality in society and have generated many effects on the mathematics curriculum. For this reason, it is necessary to pose the problem of sketching the orientations of mathematics curriculum for the new situation. In this position paper, I developed an outline based on a description of the problem situation, the demands that the world of work had already been making on the curriculum at the international level, and the research carried out by mathematics education. From these factors, I assert the significant role of critical mathematics education, particularly the motto of reading and writing the world with mathematics. I propose that orientations for the mathematics curriculum in basic education in the new normality should include ethical and political issues, statistical and financial literacy, digital skills as a part of a STEM approach, ethnomathematics from native people, and, finally, a problem-posing and problem-solving approach. In this list, ethical and political issues have primacy.
\end{abstract}

Keywords Mathematics curriculum · COVID-19 · New normality $\cdot$ Politics and mathematics education

\section{Introduction}

The COVID-19 pandemic has posed severe challenges to society and the educational system in every country around the world (Bakker \& Wagner, 2020; Burga et al., 2020). In Peru, for example, one solution established by the current legal system is the implementation of emergency measures to ensure the continuity of the educational service (Ministry of Education of Peru, 2020). However, the scenario generated allows me to affirm that such emergency measures in the curricular area of mathematics, specifically, are no longer sufficient given the various challenges that the pandemic has posed to the area, such as the

Luis Miguel Maraví Zavaleta

a20146949@pucp.pe

1 I.E. N ${ }^{\circ} 80915$ "Miguel Grau Seminario”, El Pallar, Huamachuco, La Libertad, Peru 
need to "strengthen mathematical thinking that addresses change and variation, that deals with uncertainty and knows how to extract information from data to look beyond itself" (Cantoral et al., 2020, p. 2). In this way, I agree with Bonilla-Molina (2020), who identifies the existence of an outdated curriculum even before the pandemic outbreak. Thus, I consider that new curricular orientations designed from mathematics education are necessary to face the new normality emerging from the current health crisis and its multiple effects. In order to outline the characteristics of such orientations, I will first present a brief description of the effects that the pandemic has had on Peruvian education and its relations with the emergency curriculum of basic education (which comprises pre-primary, primary, and secondary levels). Second, I will justify the need for an emerging mathematics curriculum and then outline the aforementioned orientations of this curriculum in the "new normal." Finally, I will draw the corresponding conclusions regarding the thesis presented. It is worth mentioning that this essay will focus on the curricular and social aspects that the Peruvian reality needs to emphasize. Thus, this paper is part of what Leyendecker (2015) calls the core curriculum question of what to learn: "what are the desirable aims and content of education to equip students for their role in today's and tomorrow's society and, intrinsically, how should students learn to acquire the competencies that are identified as necessary?" (p. 898).

\section{The current situation and the emergency curriculum}

In this section, I will show the effects of the pandemic on Peruvian education and its effects on the development of the curriculum for basic education. Given the severity of the impact, such effects activated provisions aimed at intervening in the curriculum in emergencies.

The consequences of COVID-19 in the education sector are serious. According to a constantly updated chronology (RPP editorial staff, 2020), the first case was detected in my country on March 5, 2020, at the time when thousands of teachers were preparing for the beginning of the school year in basic education institutions. Because of the rapid spread of the virus, the government decreed a state of national emergency for 15 days on the night of March 15. While the state of national emergency and the restrictions that it imposed continued at least until the end of 2021, the national quarantine ended on July 1, 2020, but remained in place in several regions of the country for a while. This not only caused the school year not to begin on March 16 as planned but also led to the closure of all public and private schools nationwide, with the consequent damage to the care, training, and nutrition that children and adolescents were receiving (UNICEF Peru, 2020). It was only at the beginning of April that the government decreed the start of remote learning through an emergency teaching strategy called Aprendo en casa (I learn at home), via radio, TV, and internet. However, according to UNICEF Peru (2020), since only $60 \%$ of Peruvian children and adolescents would have access to the Internet and given the existence of connectivity problems in rural Andean and Amazonian areas, I can assert that a high percentage of school-age children have been affected in their studies. Aspects of Peruvian education, whether face-to-face or remote, have been affected and have required the adoption of emergency measures.

The events described also impacted Peruvian curriculum development, especially on the recently approved National Basic Education Curriculum (NBEC). Because of an evaluation process of the previous curriculum and the recognition of new international trends in the world of work and knowledge, besides the social challenges that the country must face, 
a few years ago, the new NBEC (Ministry of Education of Peru, 2016) had been mandated. According to some authors (Bonilla \& Paz, 2018), this curriculum is the basis of the national pedagogical policy since it includes the curricular purposes set forth for pre-school, primary, and secondary education to achieve the graduation profile of students in basic education. So, the NBEC proposes the development of competencies and abilities, and the evaluation of students through defined learning standards. In the area of mathematics, there are four competencies proposed in terms of problem solving (quantity, regularity, form and movement, data management and uncertainty), which besides organizing the competencies to be developed, show the fundamental orientation of the mathematics curriculum towards problem solving. However, given the influence of the international context in which the curriculum was built, the same authors show that there are criticisms regarding its neoliberal cult, the cult of the individual, and competition (Bonilla \& Paz, 2018). This feature did not prevent the activities proposed in the I learn at home strategy from being grouped together through inter-area learning projects under environmental and intercultural approaches. In this way, the activities in the area of mathematics were considered in conjunction with activities in other areas on which a biweekly product was to be evaluated. Such activities included aspects such as racial discrimination or physical-emotional well-being, among other aspects that had already been planned in other emergency curricular initiatives established by Peruvian legislation.

In order to face the emerging health situation, the government implemented necessary emergency alternatives involving the curriculum. In 2014, the Ministry of Education introduced the Disaster Risk Reduction (DRR) approach as a curriculum intervention needed as an emergency response to disasters (Ministry of Education of Peru, 2015). Such intervention is a formal process that directs learning in emergency or disaster situations around student needs generated in the new context. This process comprises various stages in which the different levels of national education administration take part, according to the degree to which they are affected and taking into account the purposes (competencies, capacities, and learning standards) of the current NBEC (Ministry of Education of Peru, 2016). Thus, DRR-oriented topics permeate all established curricular areas (Selby \& Kagawa, 2012) as is the case, for example, with the Regional Curriculum for the Emergency developed by La Libertad regional government (La Libertad Regional Administration of Education, 2020) or the suggestions for learning experience designs stated in the Pedagogical Guidelines for the Basic Education service during the year 2020 (Ministry of Education of Peru, 2020). These curriculum documents based on the NBEC aim to address the educational emergency in a changing social and educational context with very different characteristics from those existing before the pandemic.

The facts described in Peruvian education and the measures taken to address them would seem to show that the curricular themes would not need further modification. However, the national reality related to the pandemic highlighted other aspects that the curriculum cannot ignore.

\section{The new normality and the reasons for an emergent mathematics curriculum}

This section provides the rationale for an emergent mathematics curriculum, based on the close links between the emergency and new normality, and also the social, economic, and emotional effects that characterize the situation and the impact on the general curriculum and the mathematics curriculum in particular. 
It is necessary to show that new normality and emergency are two closely related concepts. Normality has been defined as that which is "habitual u ordinario" [usual or ordinary] (Real Academia Española, n.d.) and, therefore, it has a multiple character and is connected with concrete historical conditions (Misztal, 2015). On the other hand, the word emergency has two meanings: "(1) acción y efecto de emerger (2) situación de peligro o desastre" ["(1) the act and the effect of emerging (2) hazard or disaster situation"] (Real Academia Española, n.d.). The first meaning of emergency has a special importance for this essay because, according to Corning (2002) "emergent phenomena can be defined as a 'subset' [...] of cooperative interactions that produce synergistic effects" (p. 23). In the Peruvian case, however, both meanings of emergency allow me to describe how the new normality in education could be gestated from the pandemic and the combination of phenomena such as the need to keep the educational system functioning, the rise of Internet communications (Burga et al., 2020), and the predominance of remote learning (Hughes, 2020). At the same time, the current situation influences the factors that originated it through, for example, the expansion of channels for the dissemination of curricular material on social networks (Latina editorial staff, 2020). In this way, the emergency and the new-normal are interdependent and almost simultaneous factors that generate consequences in various aspects of society. These consequences have negative and positive aspects.

Among the principal negative phenomena that are emerging because of the current pandemic and that affect the curriculum, I can indicate those that are of a social, economic, and emotional nature. Assuming that the curriculum fulfills a certain social mandate given to the educational institution (Alvarez de Zayas, 2001), and by pointing out the implications that the context poses to the school (Null, 2011), it is possible to understand that socio-economic changes impact educational structures and define the orientations of the curriculum. According to the International Labour Office (2020), due to the social isolation measures organized in each country to deal with the pandemic, high percentages of job losses, reduced working hours, and abrupt decreases in income from the informal sector, among other negative effects, have increased. In the case of Peru, which is characterized as an exporter of raw materials, the reduced demand for these will generate a major economic impact (United Nations Secretary-General, 2020), with effects that are already being felt in people's economies and jobs (Peruvian Institute of Economy, 2020; UNICEF Peru, 2020), in addition to the associated social and emotional unrest (Burga et al., 2020). Add to this the sped-up dissemination of information about the pandemic through social networks, which are not always dependable (Jandrič, 2020), the danger of selfishness generated by social isolation (Harari, 2020; Burga et al., 2020), and the increased vulnerability of Indigenous peoples to the pandemic (Correa \& Yeckting, 2020) shape a troublesome outlook. Thus, there are negative social, economic, and emotional realities that make it all the more justified that schools should no longer teach the same things as they did before the pandemic (Ministry of Education of Peru, 2015).

However, not all the phenomena emerging from the pandemic that impact the mathematics curriculum are negative. Within the social, economic, and emotional aspects, it is important to recognize the decrease in environmental pollution caused by social isolation, the rise in creativity, and the increased number of acts of solidarity as positive features of the crisis caused by the pandemic (Burga et al., 2020). Special mention should be made for creativity, whose highest expression is the high and quick development that science and technology have deployed during the crisis in areas such as medicine and genetics, among others (BBC Mundo editorial staff, 2020). It is also worth noting the significant interest shown by the public in scientific issues such as mathematical modelling, graphs, and statistically based predictions (Hinrichs, 2020), and the desire to understand these notions. This is possibly 
the most notable facet of what is only a small sample of the broad global discussion that exists on the accuracy of mathematical models related to the pandemic (Ampuero \& Carrasco, 2020; De la Torre et al., 2020; FT Visual \& Data Journalism team, 2020; Pais, 2020). Likewise, resilience and honesty, along with solidarity, were experienced in many ways, especially as a response to borderline situations (Burga et al., 2020). Therefore, the social responsibility assumed by the curriculum and its development cannot leave aside the positive aspects that the pandemic has left on our planet and, therefore, in my country. Consequently, the mathematics curriculum is impacted by social phenomena with all their facets.

Like all sciences, mathematics has in its history moments where social phenomena influenced its activity and, therefore, its curriculum and teaching. It is known that mathematics develops according to social needs (Ribnikov, 1984) and I could say the same thing of school (Renert, 2011) and curriculum (Chevallard et al., 2005). According to this evolution, some mathematical subjects appear and others disappear and new occupations create total or partial curricular changes (Karp \& Furinghetti, 2016). Moreover, even before the pandemic, some authors had indicated some trends within the world of work that schools around the world should have considered (International Labour Organization, 2020; Bonilla-Molina, 2020). These trends led Marope et al. (2017) to suggest some competencies or skills that should be included in the curriculum, such as creativity, digital skills, literacy (financial, scientific, information management), intercultural skills, values associated with perseverance or responsibility, and disciplinary knowledge. In the current circumstances, these skills and values need to be developed in the multiple aspects originated by the pandemic, which initiates a debate, for example, about socially shared practices "that allow for the articulation of what is taught in school with what is used in life" (Cantoral, et al., 2020, p. 15). Therefore, along these lines, it remains to be seen how the new normal and the emerging factors of the pandemic could shape the curricular orientations for the mathematics curriculum in my country.

\section{Orientations of the emerging curriculum for the new normality from mathematics education}

In this section, I outline the main orientations of the curriculum that should be drawn up in mathematics education based on the conditions of new normality in Peru. For this, I will briefly discuss the relationship between the orientation of a curriculum and its content, I will point out the role of research in the curriculum's construction and, finally, the features of the orientations proposed in dialogue with some studies or Peruvian experiences linked to the classrooms.

The mathematics curriculum has an orientation and multiple dimensions that underpin its implementation. Rico and Lupiáñez (2008) emphasize, precisely, that the curriculum is a proposal to act and point out four fundamental aspects where such action could be carried out: abstraction, cognitive power, ethical character of mathematical knowledge, and utilitarian purpose. In this sense, proposals such as the one reported by Merchant (2015) on mathematical contents and other topics related in three curricula from different countries would be included. The curricular developments already mentioned to face the emergency in Peru (La Libertad Regional Administration of Education, 2020; Ministry of Education of Peru, 2020) are also cases of proposals for action in the dimensions mentioned by Rico and Lupiáñez (2008), which address the area of mathematics. However, a superficial glimpse at these works could suggest that mathematics curriculum assumes mathematical 
content is the most important thing (Chevallard et al., 2005). In fact, and as previously indicated, it was the purpose or curricular orientation signed by the DRR approach that made it possible to insert or integrate certain contents according to social or economic problems of the Peruvian context. Thus, the construction of the curriculum is directed by a certain orientation or focus that is always present (Null, 2011). However, an important condition for planning goal-oriented action in these or other curricular components is found in the organization of education research activity.

I base the organizational prerequisites for orienting the mathematics curriculum that emerges under the conditions of the new normality, among other factors, on the scientific work and the active participation of teachers in it. Educational research in Peru is recognized in normative documents as an area of teaching work (Ministry of Education of Peru, 2018). Since scientific-educational activity is the aspect where scientific knowledge is built from pedagogical problems to solve them (Chirino \& del Canto, 2018), its importance for the organized construction of the mathematics curriculum is vital, as other experiences have shown (Hart \& Martin, 2018; Potari et al., 2018). In Peruvian Mathematics Education, there is research that covers different subjects linked, directly or indirectly, to the curriculum and that has influenced its building (Osorio et al., 2018). The majority of the research is developed by teachers (Salazar \& Gaita, 2015; Gaita et al., 2020) and by academics grouped in communities or networks (Osorio et al., 2018), usually within universities or higher institutes of teacher training. Also important are the mathematics teaching experiences that have been systematized and published by the National Fund for the Development of Peruvian Education (FONDEP, in Spanish). In this way, the development of the mathematics curriculum is guaranteed by the persistent work of teachers and academics who carry out scientific educational activity, which allows them to start, organize, act, and investigate the different orientations and practices that characterize the curriculum in the new normality.

The main orientations of the emergent mathematics curriculum consider the aspects that have emerged from the problems and phenomena that characterize the new normality, such as ethical-political, statistical and financial literacy, digital skills as part of a STEM approach (Science, Technology, Engineering, and Mathematics), ethnomathematics of native peoples, and problem solving and problem posing. These directions are suggested from the aspects considered by Rico and Lupiáñez (2008) for implementing the mathematics curriculum and partially agree with the traits pointed out by Bonilla-Molina (2020) to describe the educational trends accentuated by the pandemic. Moreover, the features proposed are based on the general curricular challenges that schools should face at the global level (Marope et al., 2017), the urgent acceleration of some of them with the current pandemic (Hughes, 2020), and the complex social and economic situation that the pandemic has generated (International Labour Office, 2020; United Nations Secretary-General, 2020, Burga et al., 2020). All these features have particular manifestations in each country. For this reason, the outline of the orientations of the emerging mathematics curriculum regards the recent research and experiences carried out in Peruvian mathematical education. From my point of view, the central place of the orientations has an ethical-political dimension, which steers the other orientations already mentioned. In the following, I will sketch each one of them.

\subsection{Ethical and political issues}

The guiding orientation of the emerging curriculum is at the nexus of ethics, politics, and mathematics. The main reason for this statement is that if the global situation generated 
by the pandemic proposes, as Harari (2020) states, to choose global solidarity to face the disease and its effects, such choice goes through political decisions oriented towards an ethical purpose (Fabelo, 2003). Precisely, the way in which mathematics can be harmful or beneficial to the human community depends on these decisions (Ernest, 2018). In this line, Engelbrecht et al. (2020) indicate the importance of critical mathematical education to face social inequalities from mathematical education in the current circumstances. In the Peruvian case, this implies going beyond the actual curricular features, which already included aspects such as interculturality and gender equity (Bonilla \& Paz, 2018) and which were considered in distance teaching topics (Direction of Educational Services in Rural Areas, 2020). Precisely, to make concrete the guiding orientation proposed here and from Freirean positions, I propose with Gutstein (2018), then, that teaching in a critical way in our days is not an option, but a necessity. I maintain that the main theoretical elements of Gutstein's work are important to organize my essay, so I outline the relevant aspects below.

The central thesis of the emerging mathematics curriculum and its guiding orientation is found in the reading and writing of the world through mathematics. This foundation, present in Gutstein (2018), develops the theses of Freire and Macedo (2005) to investigate the reasons for social injustice (reading the world), manifested through inequality of opportunity or discrimination (Gutstein, 2003), generate critical consciousness and then, "challenge, in words and actions, oppressive acts and structures" (Gutstein, 2006, p. 4) (writing of the world). Both processes are interrelated and allow students to develop social and personal commitment while learning mathematics and vice versa since they allow them to problematize reality and search for answers. Three types of knowledge are involved in this interaction: community knowledge (or popular knowledge, related to personal experiences), classical knowledge (from academic mathematics), and critical knowledge (reading the world with mathematics) (Gutstein, 2016). So, in this dynamic, the pedagogicalmathematical objectives (reading the mathematical world, succeeding academically in the traditional sense, and changing personal orientations towards mathematics) are not left out (Gutstein, 2006). To achieve these purposes, the permanent interconnection of community knowledge, classical knowledge, and critical knowledge is considered to obtain generative themes. They comprise "the dialectical relationship between the key social contradictions in their (people's) lives and how they perceive them and interact with them" (Gutstein, 2016, p. 458). In this way, generative themes should consider aspects coming from the social problems linked to the life of the students locally or distantly while considering the primordial character of the knowledge coming from the community. One of the fundamental ways in which these topics can be integrated into the classroom is through projects (Gutstein, 2007) supported by a mathematics curriculum whose orientation towards realism favors the proposal (Gutstein, 2006). This is how the reading and writing of the world are made concrete through mathematics.

A case in which the central thesis of the guiding orientation could be developed is gender inequality. In Peru, the troubles associated with gender inequality, a phenomenon that has deep-rooted social and cultural characteristics, have been aggravated by the pandemic (Mannarelli et al., 2020). One work that focuses on this inequality from the perspective of mathematics education developed in Peru is Chávez's (2020) analysis of some Peruvian school mathematical textbooks under a gender approach and with the tools of the Ontosemiotical Approach (OSA) such as the analysis of social norms and socio-mathematical norms involved in teaching and learning processes (Godino et al., 2009). In Chávez's work, some norms that reinforce gender stereotypes in problem-solving processes are diagnosed by analyzing certain parts of the textbooks. Even though some of the textbooks' problems would have been written under the gender equity approach emanated from NBEC, the 
complex reality that emerged from the pandemic seems to have overtaken the approach. For this reason, under the critical foundation aforementioned, my proposal considers that the work of Chávez (2020) contributes with elements that can be taken advantage of to create critical conscience from the community and classical knowledge and, later, to create generative themes with similar problems, as suggested by Gutstein (2007). Thus, while students are reading and writing with mathematics, the nexuses between this science, ethics, and politics are concretized in the teaching of mathematics to contribute to overcoming a traditional inequality.

\subsection{Statistical and financial literacy}

Statistical and financial literacy are the second orientation proposed, which has also theoretical and practical elements belonging to reading and writing the world with mathematics. Because statistical literacy is the adult ability to interpret statistical information and discuss the reactions to such information (Gal, 2002), Watson et al. (2018) assume that everyone would have got this ability if they had studied in a way linked to the practice of statistics. Precisely, the current situation requires the development of statistical literacy skills through the practice, given the great dispersion of information and use of data for decision-making. Peru has not been an exception to this reality (Morel, 2020), which poses the challenge of using and analyzing data under the critical guiding orientation mentioned above. Along these lines, a proposal derived from Gutstein (2006) can be considered, which affirms the possibility of reading and writing the world with statistics (Weiland, 2019). In Peru, Osorio et al.'s (2020) work is connected to that purpose. Their work examines the potential of the PPDAC cycle (Problem-Plan-Data-Analysis-Conclusions) for the development of capacities linked to the elaboration of statistical studies. In this experience, the teachers are trained to develop this cycle with their students. In this way, students pose problems that can be addressed with the help of statistics; they work collaboratively with their teachers and arrive at critical ideas about the data provided and their context. Their proposal could be critically reinforced if the problems raised by the students were inscribed within the generative themes and were developed from community knowledge, as shown by similar experiences developed by Gutstein (2006). In this way, statistical literacy with a critical approach can be achieved.

On the other hand, financial literacy is important because it allows "understanding of financial concepts and risks [...] to improve the financial well-being of individuals and society, and to enable participation in economic life" (OECD, 2017, p. 85). The need for such understanding and participation has been accentuated in my country with the pandemic at its peak (Trivelli, 2020). However, the problematic aspect of this activity is that, according to Arthur (2012), it would be linked to consumerism, individualism, and other features linked to the capitalist economic model. According to this researcher, a critical approach to financial literacy needs to recognize this aspect and study the historical economic processes that allowed capitalism to become the predominant economic model. Experiences connected to this purpose have already been considered in critically focused mathematics classes (Peterson, 2015). In Peru, even though the proposals oriented towards critical financial literacy have not yet understood such aspects, they meet conditions that can be taken advantage of to reach the mentioned purpose. For example, Chuquisana (2015) focuses on simple and compound interest topics in training teachers to deal with the over-indebtedness of Peruvian families. The community knowledge and the classical knowledge can interact (Gutstein, 2016) to understand how the situation of 
over-indebtedness was reached and why some financial institutions seem to encourage it. In this way, the dynamics of debt creation and related consumer habits could be exposed and subjected to critical action. So, financial literacy connected with reading and writing the world with mathematics can be gained.

\subsection{Digital skills as part of STEM}

The third proposed orientation considers that data or financial management requires the use of technology that, most times, is associated with computers. Given the high level of development reached by science and technology in the current times, high use of digital tools is necessary. With the pandemic blast and the closing of schools, the digital scenario has become one space to overcome adversity (Rappoport et al., 2020). However, the effects of the pandemic on the labor field, coupled with pre-existing global demands (Marope et al., 2017), reveal the need to use technology, and especially digital elements, in a sophisticated manner. Because of this, one way of considering it would be found in the STEM approach, since, according to Crippen and Antonenko (2018), cyberlearning has become a central skill of this approach. However, the existence of limits and dangers in ignoring ethical issues in mathematics (Ernest, 2018) and in technology (Chesky \& Wolfmeyer, 2015) has generated a critical approach to STEM that is in line with the guiding orientation of this paper. The critical ingredient shows that "technology in STEM education be a responsive activity in which scientific knowledges are applied (sic) to global environmental and social justice" (Chesky \& Wolfmeyer, 2015, p. 87). So, Trombly et al. (2020) point out that STEM experiences are needed to reflect (and act) on the role that science plays in marginalizing or liberating groups. In this way, the socially unfair aspects created by the STEM approach and mentioned by Morales-Doyle and Gutstein (2019) can be taken to create a renovated STEM approach that has elements of the classical and critical knowledge pointed out by Gutstein (2016).

In Peru, the critical renovation of the STEM approach has not been developed on a wide scale because the approach itself has not been disseminated. Although there are efforts by private enterprise and the Peruvian National Council of Science and Technology agency (CONCYTEC in Spanish) to spread information about the STEM approach (CONCYTEC, 2020), scientific evidence has only been documented from a study carried out in school children by Tuya et al. (2019). It shows the advantages of the STEM approach for the development of critical thinking and creativity. So, not only would we be ensuring the future development of national science and technology, but also recognizing the role of issues that generate social change through the creation of critical consciousness from scientific knowledge.

\subsection{Ethnomathematics of native people}

In the fourth orientation, there is a significant place for ethnomathematics of native people due to two reasons. First of all, the motto reading and writing the world through mathematics implies the processes that take place in different social groups. Each one of these groups has different forms through which they can mathematize their reality (Alangui, 2017; Rosa $\&$ Gavarrete, 2017). One way to approach these forms of manifestation is through ethnomathematics. From this perspective, Rosa and Gavarrete (2017) indicate the role of ethnomathematics in providing balance to the curricular emphasis on competencies and abilities, 
given the contextual and community character of ethnomathematics and the individual and decontextualized meaning of emphasis on competencies and abilities. The authors propose, among other innovative ways, the orientation towards social justice, an important element in Gutstein's (2018) proposal and which Rosa and Orey (2020) describe: "Ethnomathematics emphasizes education for social justice, wherein it is necessary to empower individuals by teaching them about real-world issues and instill in them the desire to seek and work towards this goal" (p. 1150). In addition, given that the existence and culture of indigenous peoples has been seriously threatened by the pandemic (Meneses-Navarro, et al., 2020), ethnomathematics needs to be considered an orientation that crosses the mathematics curriculum to increase the contextual, community, and solidarity aspects that the current situation caused by the crisis requires (Rappoport et al., 2020). These aspects should be launched beyond the native people contexts for facilitating the communication of their mathematical knowledge.

In Peru, Reyes (2018) directed and reported an experience on the incorporation of ethnomathematical aspects from the Kañari community (in the Peruvian North Andean region) in the mathematics curriculum. In this experience, six elements are indicated for the curricular treatment:

(1) The cultural experience; (2) The systematization of ethnomathematical knowledge;

(3) The resolution of a mathematical problem of the socio-cultural situation; (4) The use of strategies and ancestral instruments; (5) The communication and representation of the resolution process; and (6) The reflection in the Peruvian north. (p. 46).

Considering the theoretical aspects guiding this essay, some of the elements mentioned by Reyes (2018) show an appropriate description of the context and community knowledge and contribute to classic knowledge. As we have seen, this description is a fundamental aspect for the creation of generative situations in Gutstein's proposal (2018). Therefore, it provides abundant material to arrive at writing the world, given the situations of social injustice in which the Kañari ethnic group develops its life (Reyes, 2018). In this way, the aspects of ethnomathematics I proposed in actual situations could be achieved.

\subsection{Problem-posing and problem-solving approach}

Finally, the fifth orientation considers the two sides of facing a mathematical problem: posing it and solving it. To justify this, I note the complex reality caused by the pandemic and described in the previous paragraphs. It is commonplace that classrooms should deal with this situation (Engelbrecht et al., 2020). Coincidently, problem solving is regarded as an important activity in mathematics. These reasons could justify the introduction of problems as key elements in a mathematics curriculum. Moreover, the theses developed by Gutstein (2018) on reading and writing the world with mathematics need to develop the activity of problem posing (Morales-Doyle \& Gutstein, 2019) as a source of critical consciousness of reality and as a part of the strategy of work with the generating themes and the different types of knowledge (community, classical and critical knowledge). In this activity, posing and solving problems would be linked to the same process.

In the case of Peruvian research, Gutstein's approach would be connected with the proposal of inquiry, creation, and solution of problems, developed by the Peruvian scholar Malaspina (2019, 2020a, b). I assert this since even though Malaspina's proposal does not mention social justice as its direct purpose, the skills and attitudes put into play around the knowledge related to students' contexts to pose problems and solve them can allow the 
development of mathematics with a critical approach. Thus, the tools contemplated specifically for the posing of problems (such as the reading of the episode taken from the reality of the classroom and the phases about the creation of problems by variation and elaboration) that allow challenging the knowledge and mathematical competencies, with the consequent emotional involvement of those who learn, would make up important aspects for the reading of the world and its writing in the way proposed by Morales-Doyle and Gutstein (2019). So, students would translate the troublesome aspects of their environment in mathematics problems to solve them and, as a result, changing and improving their actual situations.

\section{Conclusions}

In this paper, I aimed to sketch new curricular orientations in mathematics belonging to Peruvian basic education to face the new normality generated by the pandemic. As we have seen, despite the emergency measures taken to address the educational problems generated by the COVID-19 pandemic, the positive and negative social, economic, scientific, and emotional factors that shape the new emergent normality impact mathematics and, therefore, its teaching. Therefore, new curricular orientations of mathematics in basic education are needed that are adequate to the new and challenging normality. However, this normality should be better than the current situation in its varied dimensions. For this reason, from the mathematics with a critical approach, which has the motto of reading and writing the world with mathematics, and taking advantage of some Peruvian research and teaching experiences, I propose a curriculum positioned to address ethical and political issues (as a central element), statistical and financial literacy, digital skills as part of STEM, ethnomathematics of native people, and problem-posing and problem-solving approaches. With this kind of curriculum, the Peruvian people not only will be prepared for overcoming the educational impact of this and future pandemics, but also they will build a fairer society from the mathematics curriculum.

Acknowledgements I am so grateful to the following people for the email or Zoom conversations I had with them about the topics contained in this work: Uldarico Malaspina, Carlos Torres, Verónica Castillo, Miluska Castillo, Eloy Reyes (from Peru); Ricardo Cantoral (Mexico); Eric Gutstein (USA); Milton Rosa, Daniel Clark Orey (Brazil); and Maria Gavarrete (Costa Rica). Also, I extend special thanks to my friends in El Pallar (Percy, Paul, Cleyser, George, Clarita, July, Steven, Elvis, Marianela and Sofia), students, colleagues, and my mother for their helpful ideas and support in this turmoil.

Availability of data and material Not applicable

Code availability Not applicable

\section{Declarations}

Competing interests The author declares no competing interest.

\section{References}

Alangui, W. (2017). Ethnomathematics and culturally relevant mathematics education in the Philippines. In M. Rosa, L. Shirley, M. Gavarrete, \& W. Alangui. (Eds.), Ethnomathematics and its diverse approaches for mathematics education (pp. 183-208). Springer. 
Alvarez de Zayas, C. (2001). El Diseño Curricular [Curriculum design]. Pueblo y Educación.

Ampuero, A., \& Carrasco, C. (2020, May 21). COVID-19: Polémica global por la cifra de muertos que los gobiernos reportan [COVID-19: Global controversy over governments' reported death toll]. La República. https://www.larepublica.pe/sociedad/2020/05/21/coronavirus-en-peru-polemica-global-porla-cifra-de-muertos-por-covid-19-que-los-gobiernos-reportan/

Arthur, C. (2012). Financial literacy education. Neoliberalism, the consumer and the citizen. Sense.

Bakker, A., \& Wagner, D. (2020). Pandemic: Lessons for today and tomorrow? Educational Studies in Mathematics, 104, 1-4. https://doi.org/10.1007/s10649-020-09946-3

BBC Mundo editorial staff (2020, March 23). Coronavirus: 5 cosas positivas que han surgido de la crisis por la pandemia [Coronavirus: 5 positive things that have emerged from the pandemic crisis]. $B B C$ Mundo. https://www.bbc.com/mundo/noticias-51986136

Bonilla, M., \& Paz, G. (2018). The mathematical dimension of the curriculum reform in Peru. In Y. Shimizu \& R. Vithal (Eds.), Proceedings of ICMI Study 24 School Mathematics Curriculum Reforms: Challenges, Changes and Opportunities (pp. 507-514). University of Tsukuba Press.

Bonilla-Molina, L. (2020). Covid-19 on route of the fourth industrial revolution. Postdigital Science and Education, 2, 562-568. https://doi.org/10.1007/s42438-020-00179-4

Burga, M, Portocarrero, F., \& Panfichi, A. (Eds.) (2020). Por una nueva convivencia, la sociedad peruana en tiempos del COVID 19: Escenarios, propuesta de política y acción pública [For a new coexistence, the Peruvian society in times of the COVID 19: Scenarios, a proposal of policy and public action]. Fondo Editorial PUCP.

Cantoral, R., Ríos, W., Reyes, D., CantoralUriza, E., Barrios, E., Fallas, R., Castillo, D., CantoralFarfán, E., Galo, S., Flores, R., Paredes, C., García, V., \& Bonilla, A. (2020). Matemática Educativa, transversalidad y COVID-19 [Educational Mathematics, transversality, and COVID-19]. Revista Latinoamericana De Investigación En Matemática Educativa, 23(1), 1-19.

Chávez, A. (2020). Un análisis normativo ontosemiótico de los textos escolares bajo el enfoque de género [A normative and onto-semiotical analysis of school textbooks under gender]. In C. Gaita (Ed.). $X$ Congreso Internacional sobre Enseñanza de las Matemática, Actas (pp. 455-463). Pontificia Universidad Católica del Perú.

Chesky, N., \& Wolfmeyer, M. (2015). Philosophy of STEM education: A critical investigation. Palgrave Macmillan.

Chevallard, Y., Bosch, M., \& Gascón, J. (2005). Estudiar matemáticas: El eslabón perdido entre enseñanza $y$ aprendizaje [Studying mathematics: The missing link between teaching and learning]. Alfaomega.

Chirino, M., \& del Canto, C. (2018). La introducción de resultados científicos como etapa de la investigación educativa [The introduction to scientific results as a stage of educational research]. In $\mathrm{M}$. Chirino, E. Caballero, C. del Canto, C., \& M. Ramos (Eds.), La preparación para la actividad investigativa desde las escuelas pedagógicas [Preparation for research activity in pre-service teachers's universities] (pp. 69-82). Pueblo y Educación.

Chuquisana, F. (2015). Matemática financiera en la escuela secundaria para la alfabetización financiera y la formación ciudadana. Una propuesta para la formación de profesores en temas de interés simple y compuesto [Financial mathematics in high school for financial literacy and citizenship training. A proposal for teacher training in simple and compound interest topics] [Master's thesis, PUCP]. PUCP theses repository. https://www.tesis.pucp.edu.pe/repositorio/bitstream/handle/20.500.12404/6406/ CHUQUISANA_MORA_FREDDY_MATEMATICA_FINANCIERA.pdf?sequence=1\&isAllowed=y

CONCYTEC (2020). Observatorio de iniciativas STEM para Educación Básica [Observatory of STEM initiatives for Basic Education]. https://www.stem.concytec.gob.pe/index.php/acerca-observatorio

Corning, P. (2002). The re-emergence of "emergence": A venerable concept in search of a theory. Complexity, 6(7), 18-30.

Correa, N., \& Yeckting, F. (2020). Pueblos indígenas y amazónicos y COVID-19: La urgencia de una respuesta diferenciada a la emergencia [Indigenous and Amazonian people and Covid 19: Urgent and differentiated answer to the emergency]. In M. Burga, F. Portocarrero, \& A. Panfichi (Eds.), Por una nueva convivencia, la sociedad peruana en tiempos del COVID 19: Escenarios, propuesta de política y acción pública (pp. 117-140). Fondo Editorial Pontificia Universidad Católica del Perú.

Crippen, K., \& Antonenko, P. (2018). Designing for collaborative problem solving in STEM cyberlearning. In Y. Dori, Z. Mevarech, \& D. Baker. (Eds.), Cognition, metacognition, and culture in STEM education learning, teaching and assessment (pp. 89-116). Springer.

De la Torre, A., Ghezzi, P., \& Segura, A. (2020, April 19). Qué hacemos cuando el martillo no chanca [What do we do when the hammer doesn't hit?]. La República. https://larepublica.pe/sociedad/2020/ 04/19/coronavirus-en-peru-que-hacemos-cuando-el-martillo-no-chanca-lacurva-del-covid-19/

Direction of Educational Services in Rural Areas (2020). Experiencias de aprendizaje de la estrategia Aprendo en Casa radio, mes de setiembre [Learning experiences of the Learning at Home radio 
strategy, September] [Power Point slides]. https://www.docentesdelalibertad.blogspot.com/2020/08/ experiencias-de-aprendizaje-para-el-mes_30.html

Engelbrecht, J., Borba, M., Llinares, S., \& Kaiser, G. (2020). Will 2020 be remembered as the year in which education was changed? ZDM-Mathematics Education, 52, 821-824. https://doi.org/10.1007/ s11858-020-01185-3.

Ernest, P. (2018). The ethics of mathematics: Is mathematics harmful? In P. Ernest (Ed.), The philosophy of mathematics education today (pp. 187-216). Springer.

Fabelo, J. (2003). Los valores y sus desafíos actuales [Values and their current challenges]. José Martí.

Freire, P., \& Macedo, D. (2005). Literacy: Reading the word and the world. Taylor \& Francis.

FT Visual \& Data Journalism team (2020, August 9). Coronavirus tracked: The latest figures as countries fight to contain the pandemic. Financial Times. https://www.ft.com/content/a26fbf7e-48f8-11ea-aeb3$955839 \mathrm{e} 06441$

Gaita, C., Flores, J., \& Ugarte, F. (Eds.) (2020). X Congreso Internacional sobre Enseñanza de las Matemática, actas [Proceedings of the 10th International Congress on Mathematics Education]. Pontificia Universidad Católica del Perú.

Gal, I. (2002). Adults' statistical literacy: Meanings, components, responsibilities. International Statistical Review, 70(1), 1-51.

Godino, J., Font, V., Wilhelmi, M., \& De Castro, C. (2009). Aproximación a la dimensión normativa en didáctica de las matemáticas desde un enfoque ontosemiótico [An onto-semiotic approach to the normative dimension in didactics of mathematics with an ontosemiotic lens]. Enseñanza De Las Ciencias, 27(1), 58-76.

Gutstein, E. (2003). Teaching and learning mathematics for social justice in an urban, Latino school. Journal for Research in Mathematics Education, 34(1), 37-73.

Gutstein, E. (2006). Reading and writing the world with mathematics, toward a pedagogy of social justice. Routledge.

Gutstein, E. (2007). Connecting community, critical, and classical knowledge in teaching Mathematics for Social Justice. The Montana Mathematics Enthusiast, 1, 109-118.

Gutstein, E. (2016). "Our issues, our people-math as our weapon": Critical mathematics in a Chicago neighborhood high school. Journal for Research in Mathematics Education, 47(5), 454-504.

Gutstein, E. (2018). The struggle is pedagogical: Learning to teach critical mathematics. In P. Ernest (Ed.), The philosophy of mathematics education today (pp. 131-144). Springer.

Harari, Y. (2020, March 20). The world after coronavirus. Financial Times. https://www.ft.com/content/ 19d90308-6858-11ea-a3c9-1fe6fedcca75

Hart, E., \& Martin, W. (2018). Discrete Mathematics is essential mathematics in a 21st century school curriculum. In E. Hart, \& J. Sandefur (Eds.), Teaching and learning Discrete Mathematics worldwide: Curriculum and research (pp. 3-20). Springer.

Hinrichs, C. (2020). Interesting times for statistical literacy. Newsletter of the International Statistical Literacy Project, 12(1), 1.

Hughes, C. (2020). Some implications of COVID-19 for remote learning and the future of schooling. https:// www.unesdoc.unesco.org/ark:/48223/pf0000373229

International Labour Office (2020). ILO Monitor: COVID-19 and the world of work. https://www.ilo.org/ global/topics/coronavirus/impacts-and-responses/WCMS_743146/lang--en/index.htm.

International Labour Organization (2020). Global employment trends for youth 2020, technology and the future of jobs. https://www.ilo.org/global/publications/books/WCMS_737648/lang--en/index.htm

Jandrič, P. (2020). Postdigital research in the time of Covid-19. Postdigital Science and Education, 2, 233238. https://doi.org/10.1007/s42438-020-00113-8

Karp, A., \& Furinghetti, F. (2016). History of mathematics teaching and learning, achievements, problems, prospects. Springer. https://doi.org/10.1007/978-3-319-31616-1

La Libertad Regional Administration of Education (2020). Curriculo regional por la emergencia frente al coronavirus COVID-19 [Regional Curriculum for the Coronavirus Emergency COVID-19]. https://www. ugel03-tno.gob.pe/2020/03/27/\%F0\%9F\%91\%A9\%E2\%80\%8D\%F0\%9F\%8F\%AB-atencion-\%F0\%9F\% $91 \% \mathrm{~A} 8 \% \mathrm{E} 2 \% 80 \% 8 \mathrm{D} \% \mathrm{~F} 0 \% 9 \mathrm{~F} \% 8 \mathrm{~F} \% \mathrm{AB}$ publicacion-del-nuevo-curriculo-regional-por-la-emergenciafrente-al-covid-19-corregida/

Latina editorial staff (2020, April 27). EduTubers peruanos son convocados para colaborar con la educación virtual [Peruvian EduTubers are called to collaborate with virtual education]. Latina. https://www.latina. pe/tendencias/estilo-de-vida/portada/edutubers-peruanos-son-convocados-para-colaborar-con-la-educa cion-virtual

Leyendecker, R. (2015). Curriculum and learning. In N. Seel (Ed.), Encyclopedia of the sciences of learning (pp. 896-900). Springer. 
Malaspina, U. (2019). Rectángulos: Perímetros, áreas y curvas de nivel. Una experiencia de indagación [Rectangles: Perimeters, areas, and contours. An inquiry experience]. Unión, 57, 153-161.

Malaspina, U. (2020a). Indagar, crear y resolver problemas de matemáticas [Inquiring, creating, and solving mathematics problems]. In C. Gaita (Ed.). X Congreso Internacional sobre Enseñanza de las Matemática, actas (pp. 82-90). Pontificia Universidad Católica del Perú.

Malaspina, U. (2020b). Curvas crecientes y porcentajes [Increasing curves and percentages]. Unión, 58, 191-196.

Mannarelli, M., Motta, A., Yon, C., Figueroa, E., \& Soto, K. (2020). Mujeres, género y pandemia en el Perú [Women, gender and pandemic in Peru]. In M. Burga, F. Portocarrero, \& A. Panfichi (Eds.), Por una nueva convivencia, la sociedad peruana en tiempos del COVID 19: Escenarios, propuesta de política y acción pública (pp. 57-78). Fondo Editorial Pontificia Universidad Católica del Perú.

Marope, M., Griffin, P., \& Gallagher, C. (2017). Future competences and the future of curriculum, a global reference for curricula transformation. IBE-UNESCO.

Meneses-Navarro, S., Freyermuth-Enciso, M., Pelcastre-Villafuerte, B., Campos-Navarro, R., Meléndez-Navarro, D., \& Gómez-Flores-Ramos, L. (2020). The challenges facing indigenous communities in Latin America as they confront the COVID-19 pandemic. International Journal for Equity in Health, 63(19), 1-3. https://doi.org/10.1186/s12939-020-01178-4

Merchant, A. (2015). Children and disaster education: An analysis of disaster risk reduction within the school curricula of Oregon, Texas, and the Philippines [Master's thesis, Concordia University]. CU Commons. https://www.digitalcommons.csp.edu/cgi/viewcontent.cgi?article=1005\&context=cup_commons_grad_ ids

Ministry of Education of Peru (2015). Guía metodológica para la intervención del currículo por la emergencia en instituciones educativas [Methodological guide for emergency curriculum intervention in educational institutions].

Ministry of Education of Peru (2016). Currículo Nacional de la Educación Básica [National Curriculum of Basic Education].

Ministry of Education of Peru (2018). Ley de Reforma Magisterial [Teacher Reform Act].

Ministry of Education of Peru (2020). Orientaciones pedagógicas para el servicio educativo de Educación Básica durante el año 2020 en el marco de la emergencia sanitaria por el coronavirus COVID-19 [Pedagogical guidelines for the educational service of Basic Education during the year 2020 in the framework of the health emergency due to the coronavirus COVID-19]. Ministry of Education of Peru.

Misztal, B. (2015). Multiple normalities, making sense of ways of living. Palgrave Macmillan.

Morales-Doyle, D., \& Gutstein, E. (2019). Racial capitalism and STEM education in Chicago public schools. Race Ethnicity and Education., 22(4), 525-544. https://doi.org/10.1080/13613324.2019.1592840

Morel, J. (2020). Más allá de \#abrirlosdatos: La administración de la información [Beyond of \#openingdata: Management of information]. In R. Asensio (Ed.), Crónica del Gran Encierro, Pensando el Perú en tiempos de pandemia (pp. 159-164). Instituto de Estudios Peruanos.

Null, W. (2011). Curriculum from theory to practice. Rowman \& Littlefield.

OECD (2017). PISA 2015 assessment and analytical framework: Science, reading, mathematic, financial literacy and collaborative problem solving. https://doi.org/10.1787/9789264281820-en

Osorio, A., Aredo, A., Bonilla, M., Castro, O., Isidro, L., Quintanilla, C., Sabino, C., \& Villavicencio, M. (2018). Report on Mathematics teacher preparation in Peru. In Y. Yamamoto, \& U. Malaspina (Eds.), Mathematics teacher education in the Andean Region and Paraguay, a comparative analysis of issues and challenges (pp. 75-104). Springer.

Osorio, A., Sáenz, S., Alhuay, Y., \& Olivares, N. (2020). La creación de problemas en gestión de datos y la formación de profesores de secundaria [Problem-posing in data management and pre-service high school teachers]. In C. Gaita (Ed.). X Congreso Internacional sobre Enseñanza de las Matemática, actas (pp. 302-311). Pontificia Universidad Católica del Perú.

Pais, A. (2020, April 20). Modelos matemáticos de coronavirus: Por qué el más popular para predecir la curva del covid-19 considera a los muertos como "recuperados" [Mathematical models of coronavirus: Why the most popular predictor of the covid-19 curve considers the dead to be "recovered]. BBC Mundo. https:// www.bbc.com/mundo/noticias-52455414

Peruvian Institute of Economy (2020). Cuarto informe: Análisis del impacto económico del Covid-19 en el Perú [Fourth report: Analysis of economic impact of Covid-19 in Peru].

Peterson, B. (2015). Weaving social justice in elementary mathematics. S. Mukhopadhyay, \& B. Greer (Eds.). Proceedings of the Eighth International Mathematics Education and Society Conference (pp. 61-82). Ooligan.

Potari, D., Psycharis, G., Sakonidis, C., \& Zachariades, T. (2018). Collaborative design of a reform-oriented mathematics curriculum: Contradictions and boundaries across teaching, research, and policy. Educational Studies in Mathematics, 102, 417-434. https://doi.org/10.1007/s10649-018-9834-3 
Rappoport, S., Rodríguez, M., \& Bressanello, M. (2020). Enseñar en tiempos de COVID-19. Una guía teóricopráctica para docentes [Teaching in times of COVID-19. A theoretical-practical guide to teachers]. UNESCO.

Real Academia Española. (n. d.). Diccionario de la lengua española [Spanish dictionary]. Retrieved May 15, 2020, from https://dle.rae.es/

Renert, M. (2011). Mathematics for life: Sustainable Mathematics Education. For the Learning of Mathematics, $31(1), 20-26$.

Reyes, E. (2018). Incorporación de la Etnomatemática de los Kañaris de Lambayeque en la práctica docente intercultural bilingüe. [Integration of the Kañaris ethnomathematics from Lambayeque in the practice of bilingual intercultural teaching]. Anales de la Universidad Central del Ecuador, 376(1), 35-56.

Ribnikov, K. (1984). Historia de las matemáticas [History of mathematics]. Mir.

Rico, L., \& Lupiáñez, J. (2008). Competencias matemáticas desde una perspectiva curricular [Mathematical competencies from a curriculum perspective]. Alianza.

Rosa, M., \& Gavarrete, M. (2017). An ethnomathematics overview: An introduction. In M. Rosa, L. Shirley, M. Gavarrete, \& W. Alangui (Eds.), Ethnomathematics and its diverse approaches for Mathematics Education (pp. 3-19). Springer.

Rosa, M., \& Orey, D. (2020). The role of Ethnomathematics and social justice in Mathematics Education. In Y. Morales, \& A. Ruiz (Eds.). Educación Matemática en las Américas 2019 (pp. 1146-1151). Comité Interamericano de Educación Matemática.

RPP editorial staff (2020, April 7). Coronavirus: Esta es la cronología del COVID-19 en el Perú y el mundo [Coronavirus: This is the chronology of COVID-19 in Peru and the world]. RPP Noticias. https://www. rpp.pe/vital/salud/coronavirus-esta-es-la-cronologia-del-covid-19-en-el-peru-y-el-mundo-noticia-1256724

Salazar, J., \& Gaita, C. (2015). Educación Matemática en el Perú: Avances y perspectivas [Mathematics Education in Peru: Progress and perspectives]. In X. Martínez, \& P. Camarena (Eds.), La Educación Matemática en el siglo XXI (pp. 257-276). Instituto Politecnico Nacional.

Selby, D., \& Kagawa, F. (2012). Disaster risk reduction in school curricula: Case studies from thirty countries. UNESCO.

Trivelli, C. (2020). Inclusión financiera y acceso a fondos para enfrentar emergencias [Financial inclusion and access to funds to face emergencies]. In R. Asensio (Ed.). Crónica del Gran Encierro, Pensando el Perú en tiempos de pandemia (pp. 131-135). Instituto de Estudios Peruanos.

Trombly, J., Pugalenthi, P., \& Stephan, M. (2020). Designing for ethical reasoning in mathematics [and STEM] Education. Electronic Journal for Research in Science \& Mathematics Education, 24(2), 141-157.

Tuya, F., Gonzalez, M., Salazar, S., Iraola, I., \& Ticona, R. (2019). Results between STEM and non-STEM Teaching for Integral Learning in Primary School Children in Lima (Peru). IEEE Sciences and Humanities International Research Conference (SHIRCON) (pp. 1-4). https://doi.org/10.1109/SHIRCON48091. 2019.9024744

UNICEF Peru (2020). COVID 19, impacto socieconómico sobre niños, niñas y adolescentes en Perú [COVID 19, socio-economic impact on children and adolescents in Peru].

United Nations Secretary-General (2020). Shared responsibility, global solidarity: Responding to the socioeconomic impacts of COVID-19. United Nations. https://www.unsdg.un.org/resources/shared-responsibi lity-global-solidarity-responding-socio-economic-impacts-covid-19

Watson, J., Fitzallen, N., Fielding-Wells, J., \& Madden, S. (2018). The practice of Statistics. In Ben-Zvi, D., Makar, K., \& Garfield, J. (Eds.). International handbook of research in Statistics Education (pp. 105137). Springer.

Weiland, T. (2019). Critical mathematics education and statistics education: Possibilities for transforming the school mathematics curriculum. In G. Burrill, \& D. Ben-Zvi (Eds.). Topics and trends in current Statistics Education research, international perspectives (pp. 391-411). Springer.

Publisher's note Springer Nature remains neutral with regard to jurisdictional claims in published maps and institutional affiliations. 